\title{
A Research on the Moderating Effect of Company Demographics on the Relationship between Business Combination and Current Ratio using Structural Equation Model: A Test of Agency and Transaction Theories
}

\author{
Rodiel C. Ferrer
}

\begin{abstract}
Globalization of economic activities created opportunities and threats for companies of different industries to be constantly evolving to compete with local and global competitors. For firms in emerging economies to be ahead of the pack, mergers and acquisitions are the way to go. M\&As allow companies to expand faster as it assist them penetrate new markets and cross-sell into different customer bases, improve access to capital, and provide greater advantages over its competitors. With the noticeable relevance of business combination activities, this study aimed to determine whether company demographics strengthens or weakens the relationship between business combination and current ratio. Structural Model Equation (SEM) approach was used to analyze the data derived from 25 publicly listed companies in the Philippines over a 15-year horizon, 2000 - 2015. Findings suggest that there are direct relationships between business combination and current ratio as well as company demographics and current ratio. Also, the moderation of company demographics was proved to have a significant effect on the existing relationship of the independent and dependent variables. Agency and transaction cost theories supported the given results.
\end{abstract}

Index Terms-Business Combination, Current Ratio, Company Demographics, Agency Theory, Transaction Cost Theory

\section{INTRODUCTION}

Through the liberalization and deregulation in the competitive Philippine market setting, several industries nowadays engage in the merger and acquisition activity as a tool for strengthening their competitive advantages. Most companies believe that unification of power and control over the markets is a cost-effective method to fuel expansion and to create multiple growth opportunities.

One strategy that is essential for the survival and wellbeing of a firm in this hostile environment can be employed through corporate expansion (Harvey, 2015). However, businesses do not completely resolve the previously mentioned problem by aiming only for continuity. Most companies aspire to gain competitive advantages as well since business owners and stakeholders believe that leverage is one of the keys that support business endurance. Due to this, small businesses sometimes join forces with the larger companies by way of merger, acquisition, or consolidation — in other words, business combination.

Revised Manuscript Received on August 05, 2019.

Rodiel C. Ferrer, De La Salle University, Metro Manila, Philippines.

(E-mail: rodiel_ferrer@dlsu.edu.ph)
Business combination is an event or process whereby two or more companies combine with one company obtaining control over the other. According to Kumar and Bansal (2008), evaluating the effects of merger and acquisition (M\&A) transactions have been a difficult thing to accomplish for economic researchers because varying approaches are used in previous studies. In spite of the benefits expected from a business combination, negative consequences might still arise due to the lack of uniformity in the results gathered from previous studies and/or depending on the nature of how business combination was implemented. In light of this, the study wanted to find out: "What is the moderating effect of company demographics on the relationship between business combination and current ratio?"

\section{BACKGROUND OF THE STUDY}

\section{Agency Theory}

The study of management accounting focuses mainly on evaluating the performance and problems with regard to the control of the company. This includes monitoring the behavior principals and agents when it comes to investments to help reduce the agency problem. The agency theory helps explain the relationships between organizations by pointing out the inefficiency in relation to buyer and seller caused by information asymmetries and opportunistic motives such as altering of results to manipulate reported results. It helps describe a manager's behavior and the impact of such on the value of information in managerial accounting. The agency theory is beneficial in this sense because it forces businesses to take account of the value of their management accounting techniques.

\section{Efficient Market Hypothesis}

Efficient market was defined by Eugene Fama in one of his articles as "a market with great number of rational, profit-maximizers actively competing, with each trying to predict future market values of individual securities, and where current important information is almost freely available to all participants." He also mentioned that there are three forms of efficiency - weak, semi-strong and strong. These three only differ in the level of information that is 

and Current Ratio using Structural Equation Model: A Test of Agency and Transaction Theories

presented in the market. Furthermore, EMH indicates that if the stock market is deemed efficient, the stock prices reflected relevant information such as pending mergers or acquisitions of different companies.

\section{Transaction Cost Theory}

As stated by Hennart (2001), transaction cost theory focused on the problem that arises when one organizes interdependencies amongst individuals. He argued that firms arise when they are the most efficient institution that can organize these interdependencies (Hennart, 2001). In a study conducted by Ferrer (2012), a framework for transaction cost was presented wherein he stated that companies usually incur two types of transaction costs: first being external and second being internal in nature. These external transaction costs are the costs that a company would incur if it were to engage in any transaction with a different company. Internal transaction costs, on the other hand, were expenses that the company would incur if it wants to produce its products by itself.

\section{REVIEW OF RELATED LITERATURE}

\section{Business Combination}

When an acquirer gains control of one or more businesses, this transaction is referred to as a business combination. It is important to note the difference between an asset acquisition and a business combination as the former happens when assets acquired are not a business. There are many reasons for mergers and acquisitions to take place but these motives revolve around one key idea, and that is to increase and improve the financial performance and growth in shareholder value of the acquiring company.

\section{Liquidity}

Cash, being the most liquid asset is often correlated to liquidity and thus the definition of liquidity generally meant the conversion of assets into cash. For any business, it is important to consider their liquidity to be able to know if they are realizing the real value of money from the assets that could be easily used. The concept of liquidity analysis is important for any business to measure their financial performance and to help them determine whether they are able to meet their short-term liabilities.

There have been mixed results when it came to the relationship between a business combination and liquidity. Several studies suggest that the business combination had a significant negative effect on the liquidity of the company and the probable reasons associated to this is because the acquisition might have used up the pocket money. The measure of the liquidity ratio helps to act as a financial metric to know the ability of a business to pay off curent debt and obligations.

\section{Company Demographics}

Demographics alone is the statistical characteristics of human populations used specially to identify markets. In this study, demographics was specifically used to study statistical characteristics of different publicly listed companies here in the Philippines. Indicators used for company demographics in this research were company size and industry type. Several studies have used company size as an exogenous variable in measuring financial performance through different financial ratios. But Rauch et al. (2009), found out that the size of a company can be used as a moderating variable to further strengthen the relationship between the independent and the dependent variable.

Another study conducted by Ali et al. (2016) looked into the moderating effect of firm size on the relationship between management participation and firm performance. The researchers will adopt this article for its use of firm size as a moderating variable because this is in line with our intended use of firm size as a moderating variable as well. This study was able to find "that management participation in strategic planning had a significant effect on both the financial and non-financial performance indicators of the manufacturing firms (Ali et al., 2016, p. 224).”

\section{Business Combination and Financial Ratios}

According to Ferrer \& Tang (2012) “one major concern for most firms is on how to measure and assess the degree of the success of M\&As." The same study suggests that businesses must measure their financial ratios before and after a merger or acquisition occurs in order for them to evaluate the benefits received from engaging in the previously stated business combinations (Ferrer and Tang, 2012).

The next study aimed to establish the trend of mergers and acquisitions in Nigeria. Omoye and Aniefor (2016) wrote their paper with the objective to determine the various implications merger and acquisition may have on profitability, leverage buy-out and shareholders' wealth (A. S. \& S .J., 2016). In order to achieve this objective, they took the financial statements and the data contained within before and after the occurence of the business combination. The McNemar test was utilized in order to test the significance of the changes to the financial ratios before and after. The chi-square test is then used to check whether the alternative or null hypotheses are accepted. The study found that mergers and acquisitions are able to enhance the various financial ratios of the firms (A. S. \& S .J., 2016).

\section{METHODOLOGY}

\section{Design-}

The design and context of this study was structured in order to provide an exploratory research. This can be attested by the attempt of the researchers to determine whether the proposed hypotheses provide a similar outcome when compared to the a priori hypotheses. Majority of the data procured are quantitative in nature specifically the current ratios of each respective acquiring company. In addition, the design of this study also provided a causal as well as a confirmatory research. It is through the attempt by the researchers to show a cause and effect relationship between two variables. In this study, the effect of business combination and company demographics to current ratio 
was tested. This study is also confirmatory because the researchers wish to confirm the a priori hypotheses gathered from previous studies that are similar to this.

\section{Sampling-}

The paper made use of total enumeration sampling method from a population of 25 companies that engaged in merger and acquisition from year 2000-2015. The data was gathered through the annual reports disclosed on either the PSE Electronic Disclosure Generation Technology portal (PSE EDGE) or the Thomson Reuters Eikon database.

\section{Research Procedures-}

The variables under this study include one independent, one moderating variable and one dependent variable. Business combination, the independent variable, was measured through goodwill or gain on bargain purchase option. While for the moderating variable, company demographics, the two mechanisms are company size and industry type. For company size, it was computed through the company's total assets while for industry type, dummy variables were assigned in order to give numerical values for the different types of industries which are: industrial, holding firms, services, mining and oil, and properties. Lastly, the dependent variable of this paper is current ratio.

This research is concerned with the direct relationships between: (1) business combination and current ratio and (2) company demographics and current ratio. This is also concerned with discovering whether or not the demographics of a company have any moderating effect on the said relationship between merger activities and the companies' liquidity. For a proper execution of this paper, there are three phases that were followed: Phase 1 dealt with obtaining consolidated annual reports of merged companies during the years 2000-2018, Phase 2 focused on the computation of current ratios and determination of company sizes and industry types, and Phase 3 was all about data analysis.

\section{Data Analysis-}

Structural Equation Modeling (SEM) is a multivariate statistical analysis technique that is applied to determine the structural relationships between variables. The main reason for the widespread use of this model is because it allows researchers to reveal effects and relationships between multiple variables, resulting to a comprehensive judgement of the diverse aspects of the study (dell'Olio, et. al., 2018). Moreover, SEM provides an effective testing strategy as well as improving method that makes the examination of the whole theoretical models possible and that can explain the cause and effect relationship of variables in a mixed hypothesis.

This study will apply SEM since the dataset has both measured and latent variables.

\section{(PLS-SEM) Measurement Model Assessment Test}

Measurement model examines the relationship between the latent variables and their measures. In order to test the significance, reliability and validity of these effects, the paper employs formative measurement model assessments in accordance to the researcher's framework.

Convergent Validity- This validity test provides evidence of construct validity wherein there exists an assumption that the different measures of hypothetical construct tend to correlate highly with each other when they are valid. This test applies as to whether each formative indicator indeed delivers a contribution to the formative index by representing the intended meaning. The strength of the path coefficient linking the two constructs is indicative of the validity of the designated set of formative indicators in tapping the construct of interest. Ideally, a magnitude of 0.80 , but at a minimum 0.70 and above, is desired for the path between formative and reflective, which translates into an R2 value of 0.64 or at least 0.50 . If the analysis exhibits lack of convergent validity (i.e., the $\mathrm{R} 2$ value of reflective < 0.50 ), then the formative indicators of the construct formative do not contribute at a sufficient degree to its intended content.

Collinearity- High correlations between two formative indicators, also referred to as collinearity, can prove problematic from a methodological and interpretational standpoint which causes multicollinearity. In assessing the said issue, PLS SEM has a built in Collinearity Statistics Section where the variance inflation factors, and tolerance are present. If the value of tolerance is less than 0.2 or 0.1 and, simultaneously, the value of VIF 5 and above, then the multicollinearity is problematic.

Significance and Relevance- This test applies as to whether formative indicators truly contribute to forming the construct. The outer weights in formative measurement models are significantly different from zero by means of bootstrapping procedure. Moreover, when indicators are assumed to be uncorrelated, the maximum possible outer weight is $1 / \sqrt{ } n$, where $n$ is the number of indicators. As the number of indicators increases, the average value of outer weights significantly decreases. Hence, it is more likely that additional formative indicators will be nonsignificant.

If outer weight is nonsignificant but outer loading is greater than 0.5 , the indicator should be retained. However, if the outer weight is nonsignificant but the outer loading is otherwise, the significance of the outer loading should be tested further. If the outer loading results in a nonsignificant state, then the removal of the formative indicator is a must.

\section{PLSE-SEM: Moderation Analysis-}

In this study, moderation analysis was performed to determine the intensity of the moderating variable on the existing relationship between the independent and dependent variables. Moderating variables used in this study are company size, industry type, and years in business which were representations of company demographics. The three mentioned variables are tested along with the direct relationship between business combination and financial ratios. For a moderation to be considered as full, there requirements must be met: 1) hypothesis regarding the moderating effect should be significant, 2) hypothesis regarding the moderating variable and the dependent variable should be insignificant, and 3) hypothesis regarding 

and Current Ratio using Structural Equation Model: A Test of Agency and Transaction Theories

independent and dependent variables should be insignificant.

\section{Regression Analysis-}

The following regression models were used to measure the direct effect of business combination on current ratio, direct effect of company demographics on current ratio, and moderating effect of company demographics on the relationship between business combination and current ratio. The current ratio gathered in this study was measured through a statistical software, SMART-PLS:

Direct Effect of Business Combination on Current Ratio:

$\boldsymbol{C R}=\beta_{0}+\beta_{1} B C+\varepsilon$

Direct Effect of Company Demographics on Current Ratio:

$$
\begin{aligned}
& \boldsymbol{C R}=\beta_{0}+\beta_{1} C S+\varepsilon \\
& \boldsymbol{C R}=\beta_{0}+\beta_{1} I T+\varepsilon
\end{aligned}
$$

Moderating effect of company demographics on the relationship between business combination and current ratio:

$$
\begin{aligned}
& \boldsymbol{C R}=\alpha+\beta_{1} B C \\
& \boldsymbol{C} \boldsymbol{R}=\alpha+\beta_{1} B C+\beta_{2} C S \\
& \boldsymbol{C} \boldsymbol{R}=\alpha+\beta_{1} B C+\beta_{2} C S+\beta_{3}(B C \times C S) \\
& \boldsymbol{C} \boldsymbol{R}=\alpha+\beta_{1} B C \\
& \boldsymbol{C} \boldsymbol{R}=\alpha+\beta_{1} B C+\beta_{2} I T \\
& \boldsymbol{C} \boldsymbol{R}=\alpha+\beta_{1} B C+\beta_{2} I T+\beta_{3}(B C \times I T)
\end{aligned}
$$

Where $\beta_{0}$ is the intercept for the regression model, $\beta_{1}, \beta_{2}$, and $\beta_{3}$ are the partial regression/path coefficients, $\mathrm{BC}$ is Business Combination, CR is Current Ratio, CS is Company Size, IT is Industry Type, and $\varepsilon=$ error terms of the regression model.

\section{RESULTS}

\section{Descriptive Statistics}

The independent variable, business combination, was determined in this study using the actual amount of goodwill or gain on bargain purchase option. Specifically, the data used in the study was extracted from the annual reports disclosed by the chosen companies within the sample in the PSE. The annual reports collected per company in the sample of the study were 7 in total; ranging 3 years before and after the year of the business combination. The sample companies who underwent business combination for a period of 15 years, the mean BC amounted to 0.547 having 0 as the minimum for the three-year period and 1 as the maximum. Dummy variables are assigned as follows: 0 for companies who had goodwill and 1 for companies who constituted gains from bargain purchase option.

The dependent variable in this study is the current ratios. Such ratios were determined through the annual reports of the sample companies listed in the Philippine Stock Exchange (PSE). The annual reports used were the financial statements three years before and after the merger and acquisition.

The companies' mean CR is 6.22. This result indicates that the companies are highly liquid in a way that they have much more assets to finance their existing liabilities; however, the working capital management of these companies would be more efficient if these assets will be invested in long-term investments or plant assets.

The moderating role of company demographics in this research was determined using two mechanisms: company size and industry type. In the dataset, these two were represented by dummy variables. For companies with company demographics above their corresponding mean, the dummy variable set is 1 . On the other hand, for companies with moderating variables below the mean, the dummy variable assigned is 0 . This process was done to turn the mechanisms of company demographics into numerical values that can be directly comparable. In the dataset, the mean CS is 0.292 and mean IT is 0.565 . For company size, most observations were found to be below the mean and while opposite can be explained with regard to industry type. Moreover, since industry type is an exogenous variable in this study, dummy variables were used. The number of dummy variables assigned correspond to the different industries that the companies belong to. The computation of the mean played a major role for this variable since it was used as the basis for the dummy variables.

Table 1 Descriptive Statistics

\begin{tabular}{lrrrr}
\hline & BC & CR & CS & IT \\
\hline Standard Deviation & 0.498 & 33.116 & 0.455 & 0.496 \\
Mean & 0.547 & 6.22 & 0.292 & 0.565 \\
Minimum & 0 & 0.07 & 0 & 1 \\
Maximum & 1 & 354.42 & 1 & 1 \\
\hline
\end{tabular}

*BC - Business Combination, CR - Current Ratio, CS - Company Size, and IT - Industry Type

** No. of observations $=175(2000-2015)$. All data came from annual reports disclosed by PSE 
Table 2 Structural Equation Model Results for Business Combination, Current Ratio, and Company Demographics

\begin{tabular}{lcccccc}
\hline \multicolumn{1}{c}{ Models } & Coeff & CI 2.50\% & CI 97.50\% & T Stat & P values & Conclusion \\
\hline $\mathrm{Ho}_{1}: \mathrm{BC} \rightarrow \mathrm{CR}$ & -0.123 & -0.228 & -0.077 & 3.069 & 0.002 & $\mathrm{Ha}_{1}$ supported \\
$\mathrm{Ho}_{2}: \mathrm{CS} \rightarrow \mathrm{CR}$ & -0.097 & -0.219 & -0.065 & 2.448 & 0.014 & $\mathrm{Ha}_{2}$ supported \\
$\mathrm{Ho}_{3}: \mathrm{IT} \rightarrow \mathrm{CR}$ & 0.099 & -0.087 & 0.171 & 1.706 & 0.088 & $\mathrm{Ho}_{3}$ supported \\
$\mathrm{Ho}_{4}: \mathrm{BC} \times \mathrm{CS} \rightarrow \mathrm{CR}$ & 0.099 & 0.06 & 0.188 & 3.025 & 0.002 & $\mathrm{Ha}_{4}$ supported \\
$\mathrm{Ho}_{5}: \mathrm{BC} \times \mathrm{IT} \rightarrow \mathrm{CR}$ & -0.115 & -0.196 & 0.011 & 2.339 & 0.019 & $\mathrm{Ha}_{5}$ supported \\
\hline
\end{tabular}

\section{Model Fit Summary}

\begin{tabular}{ll}
\hline SRMR & 0
\end{tabular}

Chi-square

NFI
0

1

\section{Initial Goodness of Fit}

Model fit describes how well the model created by the researchers fits the data that has been put into the model. Literature usually suggests the use of 3 measurements when determining the model fit: chi-square, standardized root mean square residual (SRMR), and normed-fit index (NFI). Rules of thumb for the aforementioned measurements tell us that in order to be considered as significant chi-square needs to be more than 0.05 , SRMR has to have a score of less than 0.08 , and NFI needs to be at least 0.9. Based on these results, the chi-square was not able to meet the requirement while the other two factors satisfied their corresponding thresholds. With that, it can still be said that the model fits the collected data well.

\section{Direct Impact Examined}

There were five factors tested in relation to current ratio. This set of factors were hypothesized under these several direct effects - $\left(\mathrm{Ho}_{1}\right)$ : $\mathrm{BC}$ to $\mathrm{CR}$, $\left(\mathrm{Ho}_{2}\right)$ : $\mathrm{CS}$ to $\mathrm{CR}$, and $\left(\mathrm{Ho}_{3}\right)$ : IT to $\mathrm{CR}$. Business Combination $(\beta=-0.123, \mathrm{p}=$ 0.002) and Company Size $(\beta=-0.097, p=0.014)$ provided a negative significant effect on Current Ratio. On the other hand, Industry Type $(\beta=0.099, p=0.088)$ was deemed to have no significant effect on Current Ratio. Thus, this study fails to reject hypotheses $\left(\mathrm{Ho}_{1}\right)$ and $\left(\mathrm{Ho}_{2}\right)$, and rejects hypothesis $\left(\mathrm{Ho}_{3}\right)$.

\section{$B C$ and $C R$}

BC significantly affects $C R$. The path coefficient is 0.123 and the p-value is 0.002 (negative and significant). Therefore, hypothesis 1 has failed to be rejected. This result was consistent with the research of Ooghe, Laere, \& De Lanhe (2006). It implies that as companies engage in mergers and acquisitions, it decreases the ability of companies to pay their current obligations because liquid assets like cash, marketable securities, and short-term receivables are being used to finance the activities. Moreover, a study conducted by Shah and Khan supports the same result as well. The researchers stated that when the current ratios were compared before and after the merger, the ratios provided noticeable deteriorating figures.

\section{$C S$ and $C R$}

Similar with the first hypothesis, CS significantly affects $\mathrm{CR}$. The path coefficient is -0.097 and the p-value is 0.014 (negative and significant). Therefore, hypothesis 2 has failed to be rejected. Since most companies' investments in assets are long-term in nature, the total assets which also represent company size create an indirect relationship with current ratio (current assets divided by current liabilities). However, a study conducted by - proves an opposite result. In his study, it was concluded that for every 1 unit of increase in company size, there is a corresponding 288.4725 units increase in liquidity volume. The difference may be attributed to the fact that $86.79 \%$ of liquidity volume is explained by the variables entered in the model and those are different with the variables used in this study.

\section{IT and $C R$}

IT does not significantly affect CR. The path coefficient is 0.099 and the p-value is 0.088 (positive and insignificant). Therefore, hypothesis 3 was rejected. In a study conducted by Drever and Hutchinson (2014), the effect of liquidity on industry differences were also tested and it was found that out of 10 industries, 6 were proved to be significant. The researchers mentioned that although some determinants of liquidity are common across diverse industries, there are still some considerations that should be taken into account when analyzing liquidity (Drever \& Hutchinson, 2014). 
A Research on the Moderating Effect of Company Demographics on the Relationship between Business Combination and Current Ratio using Structural Equation Model: A Test of Agency and Transaction Theories

The Moderating Role of Company Demographics on the Relationship between Business Combination and Current Ratio

The $\mathrm{p}$ values of $\mathrm{BC} \times \mathrm{CS} \rightarrow \mathrm{CR}$ and $\mathrm{BC} \times \mathrm{IT} \rightarrow \mathrm{CR}$ are less than 0.05 hence, company demographics significantly moderate the relationship between business combination and current ratio. Moreover, their t-statistics are 3.025 and 2.339 respectively which means that the actual values of the parameter are less likely to be zero. For the moderating role of CS, it resulted to a significant positive effect on the which means that the presence of company size strengthens the inverse relationship between $\mathrm{BC}$ and $\mathrm{CR}$. One reason that could possibly attest to this is the amount of non-current assets of most companies under study are greater than the current assets so even if companies increase their investments, it would just comprise mostly of long-term assets which could result to further decreases in current ratios as companies engage in mergers and acquisitions.

For the second one, the moderating role of IT resulted to a significant negative effect. This means that the negative relationship between $\mathrm{BC}$ and $\mathrm{CR}$ is weakened by the moderation of IT. Since it was mentioned by Drever and Hutchinson (2014) that there are variations in analyzing liquidity from diverse industries, this could be the biggest factor as to why the direct relationship is weakened. Some industries have characteristics specific to them such as degree of competition, product differentiation, industry's structure and the like (Leventis and Weetman, 2004).

\section{Overall Results and Business Implications}

This study evaluated the direct relationship between (1) business combination and current ratio, (2) company size and current ratio, and (3) industry type and current ratio. Furthermore, it investigated the moderating role of company size and industry type on the relationship between business combination and current ratio. For the fulfillment of this paper, Structural Equation Model (SEM) approach using the SmartPLS software was used for data gathered on a 15-year period, specifically for the year 2000-2015. With that, various direct and moderating relationships are proven to have significance. For direct relationships, business combination as well as company size were found to have significant negative effects on current ratio. Such results mean that as companies engage in mergers and acquisitions, their liquidity represented by current ratio decreases and when their total assets are increased, which is comprised mostly of non-current assets, current ratio is decreased. Moving forward to the moderating effect of company demographics on the direct relationship between business combination and current ratio, both company size and industry type provided significant effects, positive effect for CS and negative effect for IT.

In a study conducted by Birjandi (2015), agency theory suggests that firms with less liquidity are more likely to disclose information to outside parties such as investors and creditors in order to mitigate information symmetry. Several studies claim that the reason behind this is for firms to substantiate their liquidity status (Birjandi, 2015).

To add to this, the transaction cost theory suggests that when firms coordinate with other firms or individuals, the minimization of costs that will result from this might be beneficial on the liquidity of companies. This is for the reason that cash will be efficiently used for more meaningful transactions.

\section{CONCLUSION AND RECOMMENDATIONS}

As previously mentioned, this study investigates three direct relationships and two moderating effects based on 25 publicly listed companies in the Philippines that engaged in business combination activities for the period 2000-2015. The independent variable, business combination, was measured through goodwill or gain on bargain purchase option. For the moderating role of company demographics, two mechanisms were use: company size and industry type. While for the dependent variable current ratio, it was computed by dividing the companies' current assets by their current liabilities. SEM model was used and this model was analyzed through SmartPLS software. Through the support of model fit thresholds, the researcher was able to perform the study well as the model perfectly fits the gathered data.

Because of this, Philippine companies with smaller amounts of current assets might consider taking advantage of engaging in merger and acquisition activities in order to improve their business. However, there should be a caution regarding the engagement since the disadvantages might outweigh the benefits that it can bring when this is over practiced. For potential investors and stockholders, the researcher suggests that a strategic way of investing in merging companies must be exercised given the negative effect of business combination on current ratio. The reason behind this is because decrease in liquidity could imply that companies could have assumed more current liabilities and spent cash for the merger instead of paying out its shareholders. Moreover, these third parties might also want to assess the total assets of the company before investing since it was proven that company size strengthens the negative relationship between business combination and current ratio.

When it comes to the government, the results of this research could help government in establishing regulations and incentives for potential companies that wants to engage in merging activities. Through this, businesses goal can be aligned with the government's in relationship to the Philippine Competition Commission which is to promote competition and expand business horizons. Furthermore, the academe could make use of expanding on studies between industry differences and current ratio as there are only few studies supporting such relationship. This research would be of utmost benefit to various parties such as future investors, corporations, government, and the academe.

\section{REFERENCES}

1 Akinbuli, S. (2013). The Effects of Mergers and Acquisition on Corporate Growth and Profitability: Evidence from Nigeria. Global Journal Of Business Research, 7(1)

2 Ali, M., Kihoro, J., Mukulu, E., \& Nzulwa, J. (2016) Moderating Effect of Firm Size on the Relationship between Functional Integration and Firm Performance. 
International Journal of Academic Research in Business and Social Sciences, 6(9).

3 Aniefor, S., \& Omoye, A. (2016). Mergers and Acquisitions: The Trend in Business Environment in Nigeria. Accounting and Finance Research, 5(2).

4 Anuar, M., Khan, F., Khan, S., \& Malik, M. (2014). Mergers and Acquisitions: A Conceptual Review. International Journal of Accounting and Financial Reporting, 4(2). Retrieved from: Doi:10.5296/ ijafr.v4i2.662

5 Ashfaq, K., Usman, M., Hanif, Z. and Yousaf, T. (2014). Investigating the Impact of Merger \& Acquisition on Post Merger Financial Performance (Relative \& Absolute) of Companies (Evidence from Non-Financial Sector of Pakistan). International Journal of Academic Research in Business and Social Sciences, 4(11).

6 Basit, A., Hamza, S., \& Yanan, E. (2016). Impact of Merger and Acquisitions on Firms Financial Performance: A study on United States of America. International Journal of Accounting \& Business Management, $4(2)$. Available at: http://www.ftms.edu.my/journals/pdf/IJABM/Nov201 6/159-169.pdf [Accessed 15 Nov. 2018].

7 Bianconi, M., Tan, C., Wang, Y., \& Yoshino, J. (2014) Mergers and Acquisitions and the Valuation of Firms. Journal Of Economic Literature.

8 Birjandi, H. (2015). The study effect agency theory and signaling theory on the level of voluntary disclosure of listed companies in Tehran Stock Exchange. Research Journal Of Finance And Accounting, 6(1), 174-183.

9 Chiadamrong, N. \& Sinthupundaja, J. (2015). Investigation of Thai manufacturing public firms' characteristics and financial strategies towards financial performance improvement. Journal of Economics, Business and Management, 3(3), 331-337. Retrieved from: http://www.joebm.com/papers/205-A00012.pdf

10 Camerlynck, J., Ooghe, H. and Langhe, T. (2005). PreAcquisition Profile of Privately Held Companies Involved in Take-Overs: An Empirical Study. Small Business Economics, 24(2), pp.169-186.

11 Degutis, A. and Novickyte, L. (2014). The Efficient Market Hypothesis: A Critical Review of Literature and Methodology. EKONOMIKA, 93(2), pp.7-23.

12 De Langhe, T., Ooghe, H. and Camerlynck, J. (2001). Are Acquisitions Worthwhile? An Empirical Study of the Post Acquisition Performance of Privately Held Belgian Companies Involved in Take-overs. SSRN Electronic Journal.

13 Dickinson, V., Wangerin, D., \& Wild, J. (2016). Accounting Rules and Post-Acquisition Profitability in Business Combinations. Accounting Horizons, 30(4), 427-447. doi: 10.2308/acch-51504

14 Drever, M., \& Hutchinson, P. (2007). Industry differences in the determinants of the liquidity of Australian small and medium sized enterprises. Small Enterprise Research, 15(1), 60-76. doi: 10.5172/ser.15.1.60

15 Erdogan EM, Erdogan M (2014). Effect of Acquisition Activity on the Financial Indicators of Companies: An Application in BIST. International Journal of Business and Sosial Research (IJBSR). 4(7):17-22.

16 Erel, I., Liao, R. and Weisbach, M. (2012). Determinants of Cross-Border Mergers and

i. Acquisitions. The Journal of Finance, 67(3), pp.10451082.

17 Ferrer, R. and Ferrer, G. (2011). LIQUIDITIY AND FINANCIAL LEVERAGE RATIOS: THEIR IMPACT ON COMPLIANCE WITH INTERNATIONAL FINANCIAL REPORTING STANDARDS (IFRS). Academy of Accounting and Financial Studies Journal, [online] 15(1), pp.135-150. Available at: https://search.proquest.com/openview/cf10b8671be3ccbf 4fdb74f0204ff99d/1?pq-origsite $=$ gscholar \&cbl=29414 [Accessed 27 Aug. 2019].

18 Ferrer, R. (2012). AN EMPIRICAL INVESTIGATION OF THE IMPACT OF MERGER AND ACQUISITION ON THE FIRMS' ACTIVITY RATIOS. Journal of International Management Studies, [online] 12(2), pp.6873. Available

at: https://web.a.ebscohost.com/abstract?direct=true\&profile $=$ ehost\&scope $=$ site \&authtype $=$ crawler \&jrnl $=19306105 \&$ $\mathrm{AN}=76384964 \& \mathrm{~h}=\mathrm{P} 48 \mathrm{vcYg} 2 \mathrm{VjLjTrmzA} 4 \mathrm{ESj} 1 \mathrm{~K} 8 \mathrm{Ymhs}$ 884XuIu3hMcJ\%2bjDqC83eaTLttCrO53YypEyRe5Mh GyOyu5EAVWE9H0hz9g\%3d\%3d\&crl=c\&resultNs=A dminWebAuth\&resultLocal=ErrCrlNotAuth\&crlhashurl $=\operatorname{login}$. aspx $\% 3 \mathrm{fdirect} \% 3 \mathrm{dtrue} \% 26$ profile $\% 3$ dehost $\% 26 \mathrm{~s}$ cope $\% 3$ dsite\%26authtype $\% 3$ dcrawler\%26jrnl\%3d19306 105\%26AN\%3d76384964 [Accessed 25 Aug. 2019].

19 Ferrer, R. and Tang, A. (2012). The Impact of Merger and Acquisition, Financial Ratios on Stock Price among the Industrial Firms in the Philippines. De La Salle University Manila.

20 GÜNAY BENDAŞ, F. (2015). The Effects of Acquisitions on Firm Value, Evidence from Turkey. Doğuş Üniversitesi Dergisi, 1(16), pp.79-90.

21 Gaharan, C. (2015). Reporting standards for bargain purchase option: Is the objective

i. achieved? Journal of Accounting and Finance, 15(8), 6268.

22 Harvey, S. (2015). The Role of Mergers and Acquisitions in Firm Performance: A Ghanaian Case Study. Journal Of Applied Business And Economics, 17(1), 66-77.

23 Hooper, Daire \& Coughlan, Joseph \& R. Mullen, Michael. (2007). Structural Equation Modeling: Guidelines for Determining Model Fit. The Electronic Journal of Business Research Methods. 6.

24 Jensen, M. and Meckling, W. (1976). Theory of the firm: Managerial behavior, agency costs, and ownership structure. Journal of Financial Economics, 3(4), 305-360. Retrieved from https://doi.org/10.016/0304405X(76)90026-X

25 Jensen, M.C., 2001, Value maximization, stakeholder theory, and the corporate objective function, European Financial Management 7, 297-317.

26 Johnson, G., Scholes, K. and Whittington, R. (2011). Exploring corporate strategy. Harlow [etc.]: Pearson Education.

27 Kenton, W. \& Hayes, A. (2019). Liquidity Ratio Definition. Retrieved from: https://www.investopedia.com/terms/l/liquidityratios.asp

28 Khodamipour, A., Golestani, S. and Khorram, M. (2013). The relationship between liquidity and the company size with company value in companies listed on the Tehran Stock Exchange. European Online Journal of Natural and Social Sciences, [online] 2(3), pp.1210-1217. Available at: http://european-science.com/eojnss [Accessed 25 Aug. 2019].

29 Kotsogiannis, C. (2008). Mergers and Acquisitions: Benefits For Acquiring and Target Firms. SSRN Electronic Journal.

30 Kumar, S. and Bansal, L. (2008), "The impact of mergers and acquisitions on corporate performance India", Management Decision, Vol. 46 No. 10, pp. 1531-1543. https://doi.org/10.1108/00251740810920029 
31 Laiho, T. (2011). Agency theory and ownership structure-Estimating the effect of ownership structure on firm performance. Retrieved from: http://epub.lib.aalto.fi/en/ethesis/pdf/12497/hse_ethesis_ 12497.pdf

32 Leepsa, N. M. \& Mishra, C. (2012). Post Merger Financial Performance: A Study with Reference to Select Manufacturing Companies in India. International Research Journal of Finance and Economics. 83.

33 Mailanyi, P. (2014). Effect of Merger and Acquisition on the Financial Performance of Oil Companies in Kenya. Kenya: University of Nairobi.

34 Marete, D.(2015). The relationship between firm size and financial leverage of firms listed at Nairobi securities exchange. The Degree of Master of Business Administration, School of Business, University of Nairobi. Kenya. Retrieved from: https://pdfs.semanticscholar.org/3ce4/86dfe4a5f87629e0 5a31d776239892ab0321.pdf

35 Namazi, M., \& Namazi, N. (2016). Conceptual Analysis of Moderator and Mediator Variables in Business Research. Procedia Economics And Finance, 36, 540554. doi: 10.1016/s2212-5671(16)30064-8

36 Odalo, S., Achoki, G. and Njuguna, A. (2016). Relating Company Size and Financial Performance in Agricultural Firms Listed in the Nairobi Securities Exchange in Kenya. International Journal of Economics and Finance, 8(9), p.34.

37 Ooghe, H., Van Laere, E., \& De Langhe, T. (2006). Are acquisitions worthwhile? An empirical study of the post-acquisition performance of privately held Belgian companies. Small Business Economics, 27, 223-243valuation. Journal of Accounting and Public Policy, 25, 409-434.

38 Rahmawati, A., Moeljadi, M., Djumahir, D. and Sumiati, S. (2018). How Do Agency Theory, Stewardship Theory and Intellectual Capital as a Solution for Agency Conflict?. Journal of Management Research, 10(2), p.94.

39 Renneboog, L. and Vansteenkiste, C. (2019). Failure and success in mergers and acquisitions. Journal of Corporate Finance, 58, pp.650-699.

40 Shah, Burhan Ali and Khan, Niaz, Impacts of Mergers and Acquisitions on Acquirer Banks' Performance, Australasian Accounting, Business and Finance Journal, 11(3), 2017, 30-54. doi:10.14453/aabfj.v11i3.4

41 Shergill, G. and Sarkaria, M. (1999). Impact of Industry Type and Firm Characteristics on Firm-level Financial Performance- Evidence from Indian Industry. The Journal of Entrepreneurship, 8(1), pp.25-44.

42 The Post-Merger Performance: Evidence From Italy. (2012). Chinese Business Review, 11(11).

43 Vekariya, D. (2011). Impact Of Pre-Merger And Post Merger On Financial Performance (With Reference To Private Sector Banks). Indian Journal of Applied Research, 1(5), pp.6-8.

44 Zhang, W., Wang, K., Li, L., Chen, Y. and Wang, X. (2018). The impact of firms' mergers and acquisitions on their performance in emerging economies. Technological Forecasting and Social Change, 135, pp.208-216.

45 Țițan, A. (2015). The Efficient Market Hypothesis: Review of Specialized Literature and Empirical Research. Procedia Economics and Finance, 32, pp.442449 . 